захисту ІНДЗ, що сприяли б підвищенню їх якості, розвитку дослідницьких умінь та навичок майбутніх фахівців з економіки.

\title{
Література
}

1. Алексюк А. М. Педагогіка вищої освіти України / А. М. Алексюк. - Київ : Либідь, 1998. - 239 с. 2. Бойко Н. І. Організація самостійної роботи студентів вищих навчальних закладів в умовах застосування інформаційно-комунікаційних технологій: автореф. дис. на здобуття наук. ступеня канд. пед. наук : спец. 13.00.04 «Теорія та методика професійної освіти» / Н. І. Бойко. - Київ, 2008. - 28 с. 3. Виноградов В. А. Создание информационной культуры для Европы. Доклад на VI конференции ЕКССИД, 1991 г. Кантербери, Великобритания / В. А. Виноградов, Л. В. Скворцов // Теория и практика обществ.-научн. информатики. - 1991. - № 2. - С. 5-29. 4. Дауни М. Эффективный коучинг. Уроки коуча коучей / пер. с англ. / М. Дауни. - Москва : «Добрая книга», 2005. - 288 с. 5. Дичківська I. М. Інноваційні педагогічні технології / $\quad$ I. М. Дичківська - Київ : Академвидав, 2004. - 325 с. 6. Енциклопедія освіти /Акад. пед. наук України; [голов. ред. В. Г. Кремень]. - Київ : Юрінком Інтер, 2008. - 1038 с. 7. Зырянова Н. М. Коучинг в обучении подростков / Н. М. Зырянова // Вестник практической психологии образования. 2004. - №1. - С. 46-493. 8. Королюк О. М. Дослідження проблеми організації продуктивної самостійної роботи студентів у коледжах / О. М. Королюк // Становлення і розвиток науковопедагогічних шкіл: проблеми, досвід, перспективи: [зб. наук. праць] / за ред. В. Кременя, Т. Левовицького. - Житомир: Вид-во ЖДУ ім. І. Франка, 2012.- $\quad$ С. 582-590. 9. Кузьмінський А. І. Педагогіка вищої школи: [навч. посіб.] / А. І. Кузмінський. - Київ : Знання, 2005. - 486 с. 10. Ткачук Л. Проблема розвитку позитивної самооцінки дитини у творчій спадщині В. Сухомлинського / Л. Ткачук // Наукові записки ТДПУ ім. В. Гнатюка: Педагогіка. - 2002. - №5. - С. 28-32. 11. Шайдур I. А. Організація самостійної роботи студентів педагогічних університетів на основі індивідуально-орієнтованого підходу: автореф. дис. на здобуття наук. ступеня канд. пед. наук: спец. 13.00 .04 «Теорія та методика професійної освіти» / І. А. Шайдур. - Київ, 2003. - 22 с.

$$
\text { УДК 378.015.31.[378. } 33-057]
$$

Тетяна Шепеленко

\section{ПСИХОЛОГО-ПЕДАГОГІЧНІ ОСНОВИ ФОРМУВАННЯ КОНКУРЕНТОСПРОМОЖНОСТІ МАЙБУТНЬОГО ФАХІВЦЯ ЕКОНОМІЧНОГО ПРОФІЛЮ У ПРОЦЕСІ ПРОФЕСІЙНОЇ ПІДГОТОВКИ}

Шепеленко Т. Л. Психолого-педагогічні основи формування конкурентоспроможності майбутнього фахівця економічного профілю у процесі професійної підготовки.

У статті обгрунтовано необхідність формування конкурентоспроможності у майбутніх фахівців економічного профілю, здійснено аналіз економічних і педагогічних досліджень означеної проблеми, розкрито сутність понять «конкуренція», «конкурентоспроможність», «конкурентоспроможність фахівця». Окреслено мотиваційно-ціннісний аспект, який становить психолого-педагогічну основу формування конкурентоспроможності фахівця.

Ключові слова: психолого-педагогічна основа, конкуренція, конкурентоспроможність, конкурентоспроможність фахівця, мотиваційно-ціннісне ставлення, пізнавальна мотивація, професійна мотивація, самосвідомість, професійна самосвідомість.

Шепеленко Т. Л.

Психолого-педагогические

основы

формирования конкурентоспособности будущего специалиста экономического профиля в процессе профессиональной подготовки.

В статье обоснована необходимость формирования конкурентоспособности будущих специалистов экономического профиля, осуществлен анализ экономических и педагогических исследований представленой проблемы, раскрыта сущность понятий «конкуренция», «конкурентоспособность», «конкурентоспособность специалиста». Очерчен 
мотивационно-ценностный аспект, который составляет психолого-педагогическую основу конкурентоспособного специалиста.

Ключевые слова: психолого-педагогическая основа, конкуренция, конкурентоспособность, конкурентоспособность специалиста, мотивационно-ценностное отношение, познавательная мотивация, професиональная мотивация, самосознание, професиональное самосознание.

Shepelenko T. L. Psychological and pedagogical fundamentals of competitiveness development of future economic specialists in the course of professional training.

The article shows the necessity of competitiveness development of future economic specialists. The economic analysis and educational research of various aspects of the abovementioned problem has been conducted; the scientific approaches to identification the key concepts of «competition», «competitiveness», «competitiveness of a professional» have been found. The essence of the term «professional competitiveness» has been defined as a pedagogical phenomenon; personally meaningful and professionally important personality traits have been found, their interaction provides experts with the benefits in competitive relations in the chosen professional field.

The motivational value aspect has been highlighted. It makes psychological and pedagogical basis for professional development of competitiveness and includes educational and professional reasons. The essence of cognitive motivation has been revealed, the relations of intellectual and emotional sides of educational activity are shown as a factor of formation of valuable attitude to students' future career, contributing to the transformation of the significance of objective knowledge and skills into the personal importance, which positively influences the competitiveness of an individual. The essence of personal professional identity is shown as a mechanism that regulates the activity, contributes to personal conscious improvement and professional qualities, and acts as a regulator in the competitiveness of a future professional. We have highlighted cognitive, emotional, behavioural components and given the professional structure to their general characteristics.

Key words: psychological and pedagogical fundamentals, competition, competitiveness, professional competitiveness, motivational and value attitude, cognitive motivation, professional motivation, realization, professional realization.

Входження України до європейського освітнього простору, розвиток міжнародних зв'язків та співробітництво в економічній, політичній та освітній сферах викликали до життя потребу у високопрофесійних фахівцях, здатних конкурувати не тільки на вітчизняному, але й на європейському та світовому ринках праці. На необхідності забезпечення підготовки кваліфікованих кадрів, конкурентоспроможних на ринку праці, наголошується в Національній доктрині розвитку освіти України [7]. Тому наразі актуальною стає проблема підготовки майбутнього фахівця економічного профілю як конкурентоспроможної особистості.

Теоретичні основи означеної проблеми закладено в економічних дослідженнях Д. Богині (формування конкурентоспроможної робочої сили в системі соціально-трудових відносин), Н. Глевацької (напрями забезпечення конкурентоспроможної робочої сили), О. Гришнової (професійна мобільність як чинник конкурентоспроможності робочої сили), М. Кримової (компетентністна основа формування конкурентоспроможності фахівця), В. Медведя (основи формування конкурентоспроможності фахівця) та ін.

Як зазначає Н. Ничкало, що динаміка змін на ринку праці, впливає на розвиток системи освіти, на іiі модернізацію й, відповідно, на якість підготовки виробничого персоналу, дефініція «ринок праці» як економічна категорія має бути «олюдненою», вона потребує розгляду її сутності в тісному зв'язку з людиною, розвитком їі творчого потенціалу, іiі вихованням, навчанням, трудовою діяльністю, неперервною освітою впродовж життя, його (ринок праці) доцільно розглядати передусім як педагогічну категорію [9]. 
Саме тому останнім часом у вітчизняній педагогічній науці спостерігається тенденція до зростання кількості наукових досліджень конкурентоспроможності фахівця як педагогічного феномену, зокрема: визначення сутності i змісту поняття «конкурентоспроможний фахівець» (Б. Алішев, С. Дирін, О. Філатов, Д. Чернилевський та ін.), формування конкурентоспроможного фахівця в соціальному, економічному, організаційному й педагогічному аспектах (С. Батишев, А. Бєляєв, М. Ярошенко та ін.), наукового обгрунтування узагальненої моделі особистості конкурентоспроможного фахівця (В. Довжко, Н. Кузьміна, Л. Суботіна та ін.), визначення організаційно-педагогічних умов формування конкурентоспроможного фахівця (В. Андреєв, С. Батишев, В. Сластьонін та ін.) та психологічних аспектів розвитку конкурентоспроможної особистості (М. Мітіна, В. Моляко).

Проте проблема психолого-педагогічних основ ефективного формування конкурентоспроможності майбутніх фахівців економічного профілю у процесі професійної підготовки не знайшла належного висвітлення в науковій літературі, що робить іï актуальною.

Мета статті полягає в розкритті сутності дефініції «конкурентоспроможність фахівця» як педагогічного феномену, визначенні й теоретичному обгрунтуванні психологопедагогічних основ її ефективного формування у процесі професійної підготовки у ВНЗ.

На підставі того, що система вищої освіти розвивається в контексті ринкових перетворень, дослідження педагогічної сутності конкурентоспроможності фахівця потребує насамперед визначення таких базових економічних категорій, як «конкуренція», «конкурентоспроможність», «конкурентоспроможність фахівця».

Ключовим поняттям, що віддзеркалює сутність ринкових відношень, є «конкуренція». Вивчення літературних джерел засвідчує, що термін «конкуренція» виник від латинського «concurrere» - зіштовхування і трактується як суперництво, боротьба за досягнення найвищих вигод, переваг [2], як «антагоністична боротьба між приватними товаровиробниками за найбільш вигідні умови виробництва й збуту товарів» $[8$, с. 235]. Поняття «конкурентоспроможність» в економіці пов'язується 3 поняттям «конкурентоспроможність товару», яке визначається як відносна й узагальнена характеристика товару, що виражає його вигідні відмінності від товару конкурента за рівнем задоволення потреби відповідно до витрат на ії задоволення [10].

В умовах ринкової економіки робоча сила також $є$ товаром, який, щоб відповідати попиту, повинен бути конкурентоспроможним. Згідно 3 думкою Д. Богинею, конкурентоспроможність специфічного товару «робоча сила»- це сукупність якісних $\mathrm{i}$ вартісних характеристик, що забезпечують задоволення конкретних потреб у працівниках певної кваліфікації (професії) [2].

Але суто економічне трактування конкурентоспроможності робочої сили не може безпосередньо використовуватися в педагогічному процесі. У Законі України «Про вищу освіту» зазначається, що одним з основних завдань освітньої діяльності є утвердження в учасників освітнього процесу моральних цінностей, соціальної активності, громадянської позиції та відповідальності, здорового способу життя, вміння вільно мислити та самоорганізовуватися в сучасних умовах (Стаття 26) [4].

Тому, як стверджує В. Андреєв, найважливішим чинником конкурентоспроможності, $\epsilon$ якісні параметри робочої сили, тобто сукупність властивостей, що зумовлюють здатність працівника виконувати певні види праці [1]. М. Нещадим, пов'язуючи конкурентоспроможність 3 поняттям «якість робочої сили», розуміє під нею сукупність якостей людини, що виявляються у процесі праці і зумовлюються кваліфікацією й професійними характеристиками працівника, соціально-психологічними властивостями особистості, адаптованістю до змісту й умов трудової діяльності, вміннями вдосконалювати професійні, ділові та особисті якості [8]. На думку В. Медведь, конкурентоспроможність фахівця - це володіння суб'єктом певними властивостями, які надають йому можливість розвиватись на інноваційній основі та перемагати в конкурентній боротьбі [6].

Очевидно, що в контексті педагогічної сутності конкурентоспроможності фахівця іiі 
доцільно вивчати і формувати на рівні особистісних і професійних якостей.

Систематизація різних підходів науковців до визначення якостей, які дозволяють фахівцю отримувати переваги в конкурентних відносинах в обраній для себе сфері професійної діяльності, дозволяє стверджувати, що серед домінантних для сучасного випускника економічного ВНЗ особливого значення набувають такі особистісні (гнучкість, професійна мобільність, адаптивність, комунікативність, самостійність, цілеспрямованість, ціннісні орієнтації й установки, критичне мислення, уміння «презентувати себе», розвинута інтуїція, стресостійкість, рефлективність, спостережливість, готовність до ризику, здатність до самопізнання, саморозвитку, самоосвіти) та професійні (професійна компетентність, володіння методами розв'язання різноманітних професійних завдань, здатність розв'язувати різні професійні проблеми, творчі та інтелектуальні здібності, інноваційність, креативність, проективність, прогнозування) якості.

3 огляду на окреслене вище можемо стверджувати, що в контексті педагогічної сутності конкурентоспроможність фахівця можна розглядати як складну інтегральну властивість, яка залежить від ступеня відповідності пріоритетних особистісних i професійних якостей об'єктивним вимогам професійної діяльності, що забезпечує його переваги в конкурентних відносинах в обраній для себе сфері професійної діяльності.

Теоретичний аналіз і практика надають підстави розглядати психолого-педагогічні основи формування конкурентоспроможності як комплекс елементів, основу якого складає мотиваційно-ціннісне ставлення особистості до майбутньої професійної діяльності.

Оскільки засобом професійного становлення майбутнього фахівця $є$ навчальна діяльність, то ефективність формування конкурентоспроможності спеціаліста залежить, 3 одного боку, від того, наскільки успішно здійснюється студентом оволодіння знаннями, вміннями і навичками, необхідними для майбутньої професійної діяльності, а з іншого, - від потреби в них та визнання їх цінності для професійної досконалості. Потреби усвідомлюються на «мові мотивів», які відповідають на питання, заради чого здійснюється

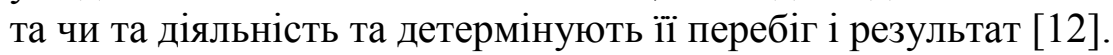

У науковій літературі мотив визначається як внутрішнє збудження до того чи того виду діяльності, яке пов'язане із задоволенням певної потреби. Сукупність стійких мотивів, які перебувають в ієрархічній залежності, створюють мотиваційну сферу особистості, у структурі якої визначають пізнавальні, професійні, прагматичні, широкі соціальні мотиви та мотиви соціального й особистісного престижу [14].

В аспекті нашого дослідження особливу роль відіграють пізнавальні мотиви. Пізнавальним мотивом називають спрямованість студента на різні аспекти навчальної діяльності (А. Маркова), внутрішню спонукальну силу, яка забезпечує рух особистості до пізнавальної діяльності, активізує розумову активність (А. Кузьмінський), спонукання студентів до активної навчальної діяльності, продуктивного пізнання змісту навчання (І. Підласий). Пізнавальна мотивація складається із оцінки студентами різних аспектів навчального процесу: змісту, форм і способів організації, 3 точки зору їх особистих, індивідуальних потреб і спрямуванні на набуття нових знань і отримання задоволення від самого процесу пізнання [12].

У сучасних умовах пізнавальна діяльність не завжди набуває особистісного сенсу і стає для студента системою цінностей. Для того, щоб навчання було вмотивованим, у студента повинен виникнути інтерес на рівні внутрішньої потреби в знаннях, вміннях та навичках, а також потреба активно діяти в напрямку їх отримання, що забезпечує зацікавлене ставлення до участі в навчальній діяльності. Чинники, що сприяють виробленню ціннісного ставлення до навчально-пізнавальної діяльності, усвідомлення її важливості для професійної підготовки, виявляються в індивідуальному, позитивному ставленні студентів до навчальної інформації.

Психологічними дослідженнями доведено, що все «інтелектуальне» може бути усвідомлене тільки через «емоційне», а позитивне емоційне ставлення до навчальної 
діяльності забезпечується, як стверджує С. Рубінштейн, мотивацією, суб'єктивною формою існування якої $\epsilon$ емоції. «Самі емоції людини являють собою єдність емоційного й інтелектуального, так само як пізнавальні процеси зазвичай створюють єдність інтелектуального та емоційного» [11, с. 552]. Тому емоційна забарвленість навчальної діяльності робить їі особистісно значущою і позитивно впливає на творчий характер пізнавальних процесів студентів, що сприяє більш швидкому і міцному засвоєнню знань, формуванню умінь і навичок, які складають основу їх конкурентоспроможності.

Не зважаючи на те, що мотиви виконують спонукальну функцію, а емоції відображають i корегують перебіг мотиваційних процесів, їх взаємозв'язок сприяє трансформації об'єктивної значущості знань, умінь і навичок у особистісну значущість, в силу чого вони стають цінністю, що позитивно впливає на формування конкурентоспроможності фахівця [3].

Але, як стверджує К. Маркова, «засвоєні знання, сформовані вміння та навички є не лише предметом навчальної діяльності, а й діяльністю професійною» [5, с. 51]. Вочевидь, формування конкурентоспроможності фахівця залежить від тих сенсів і цінностей, які вони вбачають у майбутній професійній діяльності, від того, на якому місці ієрархії цінностей перебуває цінність самої професії, тобто від професійних мотивів. Професійна мотивація як властивість особистості, є системою цілей, потреб, що спонукають студента до активного засвоєння знань, оволодіння уміннями й навичками, свідомого ставлення до майбутньої професії.

Професійна мотивація студентів значною мірою детермінується професійною спрямованістю, яка в науковій літературі визначається як найбільш узагальнена форма емоційно-ціннісного ставлення до професії, що складається із «оцінок суб'єктом ступеня особистісної значущості (привабливості - непривабливості ) різних аспектів професійної діяльності, іï змісту, умов здійснення, ... можливості творчості, роботи 3 людьми, відповідність професії здібностям і характеру» [14, с. 131].

Спрямованість на професійну діяльність стає центральним особистісним новоутворенням і має відповідні характеристики в галузях різних професій залежно від їх особливостей. У плані інтегральної характеристики праці професійна спрямованість задає ієрархічну структуру домінантних мотивів особистості й може бути представленою так: спрямованість на предметну сторону професії, спрямованість на інших учасників професійної діяльності, спрямованість на себе, яка пов'язана 3 потребою в самовдосконаленні та саморозвитку.

Досягнути високого рівня професійної мотивації дозволяє людині сформована особистісна і професійна самосвідомість. У наукових працях провідних науковців (Б. Ананьєв, Л. Виготський, О. Леонтьєв, С. Рубінштейн та ін.) поняття «самосвідомість» визначається як складний психічний об'єкт, сутність якого полягає у сприйнятті особистістю численних образів самої себе в різних ситуаціях діяльності і поведінки, в усіх формах взаємодії з іншими людьми і поєднанні цих образів в єдине цілісне утворення - уявлення, а потім у поняття свого «Я» як суб'єкта, що відрізняється від інших суб'єктів.

У поняття «професійна самосвідомість» науковці (Д. Богиня, Д. Брагина, В. Бірченко, I. Вачков, А. Маркова, Л. Мітіна, Н. Рукавишнікова) включають: усвідомлення особистістю себе як суб'єкта майбутньої професійної діяльності на основі адекватного співвідношення 3 конкретними вимогами професії до людини; систему провідних цінностей професії на рівні особистісних цінностей; процесуальну сторону професійної діяльності та позитивне ставлення до оволодіння нею. Розглядаючи професійну самосвідомість як усвідомлення студентом властивостей і особливостей власного Я, значущих для процесу оволодіння професією і в подальшому у професійній діяльності, науковці у її структурі виокремлюють такі компоненти: когнітивний (забезпечення усвідомлення себе і свого місця в системі професійної діяльності, уточнення, конкретизацію і розширення системи знань про себе, про свій «Я - образ» як особистості і фахівця-професіонала); емотивний (відображення емоційно-оцінного ставлення до себе, яке формується в результаті самооцінювання 
професійної придатності, що здійснюється на основі рефлексії, позитивного самовідношення, адекватної самооцінки свого професійного потенціалу); поведінковий (закріплення власної «Я - концепції» в готовності до професійної діяльності, спрямуванні на досягнення поставлених професійних цілей).

Основною функцією професійної самосвідомості $є$ пізнання особистістю себе як суб'єкта діяльності, результативну сторону якого становлять професійні аспекти образу «Я реально професійне» (який я є сьогодні) і «Я - ідеально професійне» (яким я хочу стати в майбутньому), що дозволяє діагностувати власні можливості в галузі майбутньої професійної діяльності задля самовдосконалення. «Пізнай себе і ти пізнаєш світ»,стверджував Сократ.

Отже, професійна самосвідомість як особистісний механізм, що сприяє свідомому вдосконаленню особистісно-професійних якостей, відіграє регулюючу роль у діяльності і $є$ пріоритетним чинником формування конкурентоспроможності майбутнього фахівця.

Викладене вище дозволяе стверджувати, що психолого-педагогічну основу конкурентоспроможності майбутнього фахівця складає мотиваційно-ціннісне ставлення до

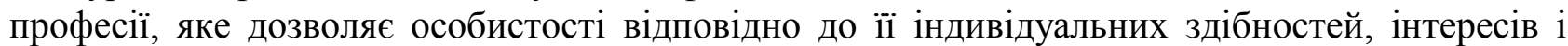
потреб брати участь і отримувати переваги в конкурентних відносинах в обраній для себе сфері професійної діяльності і забезпечує випускнику високий професійний статус на основі постійного самовдосконалення.

\section{Література}

1. Андреев В. И. Педагогика творческого саморазвития / В. И. Андреев. - Казань : Изд-во Казанского ун-та, 1998. - 318 с. $\quad$ 2. Богиня Д. П. Формирование конкурентоспособности рабочей силы в системе социально-трудовых отношений / Д. П. Богиня // Формування конкурентоспроможності робочої сили: [зб. наук. праць]. - Київ : Ін-т економіки НАН України, 2003. - С. 13-22. 3. Вилюнас В. К. Основные проблемы психологической теории эмоций / В. К. Вилюнас // Психология эмоций: тесты. - Москва : Изд-во МГУ, 1984. - С. 3-26. 4. Закон України «Про вищу освіту» [Електронний ресурс] / Верховна Рада України. - 2014. - Режим доступу: http://zakon4.rada.gov.ua/laws. 5. Маркова А. К. Психология профессионализма / А. К. Маркова. - Москва : Международный гуманитарный фонд «Знание», 1996. - 312 с. 6. Медведь В. В. Основи формування конкурентоспроможності фахівця: чинники, складові, критерії / В. В. Медведь // Теорія та методика управління освітою. 2011. - № 7.- [Електронний ресурс]. - Режим доступу : http://archive.nbuv.gov.ua/e-journals/ttmuo/ 2011_7/9.pdf. 7. Національна доктрина розвитку освіти, затверджена Указом Президента України від 17 квітня 2002 року № 347/2002. - [Електронний pecypc]. - Режим доступу : http://www.mon.gov.ua/. 8. Нещадим М. Освіта протягом усього життя - необхідна вимога до фахівця XXI століття / М. Нещадим // Шлях освіти. - 2000.- № 1.- С. 14-16. 9. Ничкало Н. Г. Професійна освіта i навчання: Проблеми зв'язку 3 ринком праці / $\quad$ Н. Г. Ничкало //Формування широкої кваліфікації робітників. Вклад ПТО у розвиток трудового потенціалу XXI століття: [зб. матеріалів підготовки у рамках реалізації українсько-німецького проекту «Підтримка реформи професійно-технічної освіти в Україні»] / [Ю. Вайс, Н. Ничкало, А. Сімак та ін.]. Ніжин : Аспект-Поліграф, 2007.- С. 134-148. 10. Политическая экономия: Словарь / [ред. М. И. Волков]. - Москва : Политиздат, 1983. - 527 с. 11. Рубинштейн С. Л. Основы общей психологии / С. Л. Рубинштейн. - Москва : Педагогика, 1989. - 485 с. 12. Токар Н. Ф. Динаміка мотивації в процесі професійної підготовки / Н. Ф. Токар // Педагогіка і психологія. - 1997. - № 4. - С. 151-154. 13. Чернилевский Д. В. Конкурентность будущего специалиста как показатель качества его подготовки / Д. В. Чернилевский, О. К. Филатов // Специалист. - 1997. - №1. - С. 29-33. 14. Якунин В. А. Педагогическая психология: [учеб. пособие] / В. А. Якунин. - Санкт-Петербург : Изд-во Михайлова В. А., 2000. - 349 с. 